\title{
The COVID-19 Pandemic in the IGAD Region: Consequence and Responses
}

\section{$\underline{\text { Redie Bereketeab }}$}

The Nordic Africa Institute, Uppsala, Sweden

Email: redie.bereketeab@nai.uu.se

\section{Abstract:}

This article examines the consequences of COVID-19 pandemic in the Intergovernmental Authority on Development (IGAD) region. In its epidemiological, as well as socio-economic dimensions, the pandemic presents extraordinary difficulties. The states in the region already suffer of dearth of basic medical equipment, medicines, personnel, health infrastructures and other health related materials. Early on, it also became clear that the Western world would not extend helping hand, in particular, with regard to crucially needed medical equipment and masks. The European Union's decision not to sell medical equipment outside the bloc sent a clear signal that the region is on its own. Releasing this the governments of the region focused on measures of prevention. They, while on the one hand introduced severe lockdown, state of emergency and curfews, and on the other began to mobilise their social capital. The consequences of the total lockdown are yet to be properly assessed; however, socio-economic impacts are already immense. The article argues that dealing with the consequences of the pandemic requires pulling together all the resources of the region that depend on effective and coherent mobilisation and organisation of resources, capacities and social capital.

Keywords:

COVID-19, pandemic; IGAD; epidemiology; socio-economic; solidarity

\section{Introduction}

This article examines consequences and responses to the COVID-19 pandemic in the IGAD (Inter-governmental Authority on Development) region. The IGAD comprises Uganda, Sudan, South Sudan, Somalia, Kenya, Djibouti, Eritrea and Ethiopia. The IGAD region, commensurate to population size, epidemiologically, is less, afflicted by the pandemic. Once the pandemic began to spread, the governments took drastic measures. The measures included closing their borders by sea, air and land; closing schools, businesses, barring public gathering, etc. Sudan, Djibouti and Eritrea, in particular, were quick to take these drastic measures (Assal 2020, Bereketeab 2020, Elhakim, Tourab and Zouiten 2020). Lockdown, social distancing, curfews and state of emergency are the main practical mechanisms enforced to contain and mitigate the impact of the pandemic. These measures might have contributed to the slow spread of the pandemic. The pandemic comes on top of serious problems afflicting the region such as drought, floods, torrential and erratic rains and desert locust (Weber 2020). Already, multitude of pathologies that include intra-and inter-state conflicts, poverty and underdevelopment, environmental degradation, youth migration and unemployment, external interventions, piracy, terrorism and radicalism devastates the region (Bereketeab 2013, Woodward 2013, Mengisteab 2014, Schmidt 2018, Yordanov 2016).

The magnitude of the pandemic is truly enormous challenge to the states who lack capacity. In its epidemiological, as well as socio-economic dimensions the pandemic presents extraordinary difficulties. The states in the region already suffer from dearth of basic medical 


\section{Economit Journal: Scientific Journal of Accountancy, Management and Finance ISSN: 2775-5827 (Online), 2775-5819 (Print)}

Vol. 1, No. 2, May 2021, Page: 110-121

Email: economitjournal@gmail.com

equipment, medicines, skilled personnel, health infrastructures and other health materials. Early on, it also became clear that the Western world would not extend helping hand, in particular, with regard to crucially needed medical equipment and masks. The European Union's decision not to sell medical equipment outside the bloc sent a clear signal that the region is on its own. Releasing this the governments of the region focused on measures that prioritise prevention underscoring the idiom 'prevention is better than cure'.

The general predictions and diagnostics concerning implications of the pandemic to Africa was extremely gloom. Estimations of the magnitude of infection and death were tallied to be in the millions. Many also envisaged apocalyptic economic and social consequences. Is there any rationality behind the gloomy predictions and diagnostics? What are the best ways to deal with the pandemic? How could the consequences of the pandemic be mitigated? The paper argues dealing with the consequences of the pandemic requires pulling together resources of the region. This could only be achieved through effective and coherent mobilisation and organisation of resources and capacities of the region.

\section{Review of Literatures}

\section{Socio-Economic Consequences and Social Mobilisation}

The pandemic would have serious consequences in two areas in the IGAD region. These are epidemiological and socio-economic. In terms of epidemiological consequence, the pandemic poses truly enormous challenges. Already, resource-stricken and marked by precarious medical situation, the pandemic brought enormous burden to the region. The primary epidemiological challenges related to the pandemic include ability to conduct proper and adequate checks of infection of the COVID-19; access to respiratory equipment; enough clinics, hospitals, beds; personnel (doctors, nurses, dressers and specialists), availability of face masks, etc. The inability to conduct proper checks, for instance, influences the reliability of data acquired in relation to numbers infected, recovered and dead. The inability to properly catalogue the infected, in turn, would impact the scale of the spread, which impacts the mitigating and prevention measures to be taken. The Imperial College is quoted as estimating a scale of between 350000 and 1450000 additional death in 2020 in Africa due to COVID19 pandemic (Cilliers et al 2020). The number of death in the region is commensurate to the size of population still low.

The second challenge is economic. Ensuing the total societal closure economic life, virtually, came to stand still. 'Lockdown and border closures will mean that economies that are already weak will face more overwhelming challenges and will slip into recession' (Weber 2020: 5). This throws people in immense hardship who already are facing veritable difficulties eking out daily living. The majority of urban population in the region subsist on informal economy, without any alternative or safety net to beef their economy. The first to suffer were these sectors of society, which are involved in an economy of hand to mouth. Their means of income was closed, have to rely on hand outs. On macro-economic level too, national economic growth is seriously affected. The effect varies, contingent on whether the economy is export and aid oriented. The World Bank, 'calculates that the 2020 downturn will likely increase sub-Saharan Africa's poverty rates by at least two percentage point, returning the continent to 2015 poverty levels and effectively wiping out five years of progress' (Cillier et al 2020: 3). 
Some of the preliminary forecasts stipulate that demands on African products such as oil and minerals will decline. According to UNECA 'Africa's growth will drop by $1.4 \%$ from $3.2 \%$ to $1.8 \%$ as a result of the coronavirus' (SPAU 2020: 2 ). The sectors that would suffer most are tourism, agriculture, manufacturing and trade (SPAU 2020). Consequently, 'the Intergovernmental Authority on Development (IGAD), the World Food Programme (WFP) and the Food and Agricultural Organisation (FAO) estimate that up to 20 per cent of the population in the region is now food insecure' (Serels 2020: 24). In terms of social consequences, closing schools means loss of opportunities of learning, particularly for vulnerable students. The poor who have no access to technology and internet could not benefit from virtual education and learning. Staying at home are also believed to have various adverse social consequences such as unplanned pregnancy, domestic violence (SPAU 2020).

To mitigate the socio-economic impact to the people, the governments initiated policy of social mobilisation. The policy of social mobilisation rests on social capital as understood,

In the African context, social capital - also called 'Ubuntu', 'Undugu' or 'Ujamaa' - means the interpersonal relationships and network that give people a sense of identity, shared responsibility and collective accountability. What social capital teaches is that we need to place the responsibility of preparing and responding to the COVID-19 on the citizens and community at large (Wakiaga 2020: 2).

The underpinning principle of building social capital is establishing social trust as currency for community engagement. The efficacy and success of social mobilisation and utilisation of social capital varies from country to country. Those with history and long tradition of popular mobilisation fare better than those who lack such social capital. In this context, Eritrea stands out. Eritrea, for instance, drawing on its long history of popular mobilisation, effectively marshalled its population inside and outside the country (Bereketeab 2020). The mobilisation takes two forms. The first pertains to responses, respect and abiding by the decisions and advices of the government concerning the lockdown, social distancing and cleanliness as preventive measures. All indications point to popular support of the measures taken by the government. It seems citizens understood the seriousness of the pandemic. The second pertains to material resources mobilisation. Those who depend on daily labour for their basic subsistence, following the lockdown, lost their ability to earn their daily bread, therefore, society have to step in and contribute. The government formed a High Level Task Force (HLTF) that began immediately issuing instructions, guidelines and rules. The formation of the HLTF was replicated everywhere Eritreans reside, including the diaspora. The model followed was a modus operandi pursued during the liberation struggle. The COVID-19 pandemic was defined as another form of challenge Eritreans gone through and came out successful. Drawing on lessons from the experience of the liberation struggle era popular mobilisation, we will successfully face this challenge too is the motto.

The best practical mobilisation mechanism is public awareness raising. People's awareness concerning hygiene, social distancing, avoiding social gathering are considered as the best mechanisms of protection that people should strictly adhere to. Video clips, short dramas and films, national newspaper, televisions and social media outlets depicted by prominent cultural, sport and social personalities were produced for awareness raising. This was compounded by street performances. Eritreans inside the country and in the diaspora are mobilised to contribute in cash and kind, which are proving to be impressive and decisive (Bereketeab 2020). Without those contributions, it would be difficult for people to survive. 
Undoubtedly, from an epidemiological point of view, government actions save life. What is getting clearer is, however, the socio-economic consequences of the pandemic could be much greater. The World Health Organisation (WHO) have cautioned that the socioeconomic related implications are much more damaging to Africans. Experts are warning that poverty and hunger related death could be considerably bigger than the COVID-19 pandemic. These warnings carry weight when we add the current drought and desert locust devastating the region in the calculation. It is, therefore, apparent that the lockdown and curfews would intensify the negative economic, social and political impact the region is already suffering from.

Another aspect that is believe to get worse is that the reduced economic growth coupled with downfall of foreign aid and remittances would lead to debt trap, poverty and inequality. When revenues at home dwindle and remittances fall short, governments would have no choice but borrow money that roll them down the road of debt trap. The economic hardship would then shoot up poverty and widen the inequality gab.

\section{Discussion}

\subsection{Potentials of Conflicts and Deficiency of State Legitimacy}

Always it is the case that unexpected calamities aggravate chronic conditions. This is true with the current COVID-19 pandemic, it would certainly reinforce all the drivers of festering conflicts and state crisis in the region. Poverty, inequality, environmental degradation, dislocation, youth unemployment and migration, mismanagement of identity diversity are typical phenomena that generate conflicts, state crisis and deficiency of legitimacy in the region (Mengisteab 2014, Bereketeab 2013, Woodward 2013). In addition to these perennial phenomena, recently, also compounding problems such as locust and erratic torrential rains and floods hit the region (Weber 2020). Therefore, the current pandemic is an addendum in an already precarious situation, thus could have the potential of aggravating the existing root causes of conflicts, state crisis and deficiency of legitimacy.

In a broad sense, there are interrelated wide range of issues that fall within the perimeters of drivers of conflicts and deficiency of state legitimacy. These include: health security, food security, human security, mainstream peace and security, human livelihood security, social welfare, economic development. Certainly, all these factors buttress festering conflicts. In theory, therefore, the pandemic could have great potential for a ggravating those factors of conflicts. Factoring in the potentials is one way of dealing with and mitigating the consequences of the pandemic.

Underscoring this, the Executive Secretary of IGAD, Dr Workneh Gebeyehu, on June 20, stated that the COVID-19 pandemic is not only a health crisis but it is a comprehensive crisis (Gebeyehu 2020). The effect is, indeed, greater in economic, social and security dimensions, he stressed. Various opinions confirm that the lockdown, curfews and state of emergency have generated many distresses. One of these distresses is the increase of gender based domestic violence. 'Since the introduction of lockdown policies in several countries, there has also been marked increase in instances of gender-based violence (GBV) and violence against children' (World Bank 2020: 4). Another one is the rise in human rights violations. The human rights violations are related to intermittent brutality of security forces in enforcing state of emergency and curfews, although in the region, so far, there are no reports of widespread, out of the ordinary, security forces brutality. Kenya witnessed riots accompanied by police brutality (SPAU 2020, Human Rights Watch 2020a). The police in Kenya are often 
accused of use of excessive force against demonstrators. Related to curfews and public gathering, and particularly targeting vendors, Human Rights Watch have reported that Kenyan police used widespread excess of force (Human Rights Watch 2020a). The same Human Rights Watch have also filed reports of excessive use of force in enforcing lockdown in Uganda (Human Rights Watch 2020b). There are also accounts of scaled-up corruption within the police force who use the enforcement of lockdown and curfews for extortion, looting and bribe (Human Right Watch 2020b). The restrictions of movement are adversely affecting the livelihood of people. Therefore, unless the state is coming forth with basic provisions it will be not only difficult to enforce it but also could induce widespread uprising that further erode legitimacy. This would be exacerbated, if the curfews, state of emergency and lockdown last longer.

The provision of basic services is related with another dimension of state-society relation, notably state legitimacy. One of the cardinal functions of the state is service provision. Social contract is embedded in the double functions defining state-society relations, where the state delivers amenities while society confers legitimacy. A state that fails with its cardinal functions also fails to elicit legitimacy. In broad sense, state legitimacy in the IGAD region is weak (Bereketeab 2020a). In addition, there exists variance among the states with regard to their legitimacy capital. The transitional government in Sudan that came to power following the fall of the old regime enjoys broad legitimacy therefore the degree of acceptance of the measures taken by the government is relatively high. The same could be said with the government in Ethiopia (Weber 2020). The state of Eritrea elicits its legitimacy from revolutionary credentials. The delivery of independence embedded in the incredibly enormous sacrifices bestows legitimacy on the state that induce people to tolerate measures taken by the government (Bereketeab 2009). Somalia and South Sudan are in a worse situation due to the ongoing conflicts. Two third of the population in Somalia is dependent on food aid as well as 2.6 million of the population are internally displaced. In South Sudan, 1.5 million are internally displaced. AMISOM in Somalia and UNMISS in South Sudan have overtaken one of the cardinal functions of the state, the delivery of peace and security. The government of South Sudan, 'outsourced the provision of basic supplies for its population to international aid organisations, it is not expected to take on management tasks in this crisis' (Weber 2020: 2).

Broadly, so far, the COVID-19 pandemic have not yet aggravated the conflict situation in the region. As mentioned, there have been reports that in a number of occasions riots occurred in Kenya in conjunction with lockdown, state of emergency and curfews. In Somalia, also Al-Shebab is reported to have intensified attacks against government forces. The response to the UN Secretary General call for temporary ceasefire have therefore been different. While the various armed groups in Sudan have heeded to the call and declared ceasefire, Al-Shebab, in Somalia seem to have chosen to intensify its military operations (Weber 2020). This could be juxtaposed against, occasional excessive use of force against street vendors and those who gather in violation of curfews in Uganda and Kenya.

It is becoming apparently clear that more than the pandemic, the lockdown and curfew would take more life in Africa in general and the IGAD region in particular. The lockdown and border closure have rendered people unemployed and particularly the youth. 'This could exacerbate terrorist attacks, violent extremism and youth radicalisation' (SPAU 2020: 18). The pandemic also have a political consequences. Elections in Ethiopia and Somalia, scheduled for 2020 have been postponed. The postponement have enraged the opposition adding additional fuel to the already precarious political situation in the countries. 


\subsection{IGAD and the COVID-19 Pandemic}

Since its formation in 1986, the IGAD stood in the face of three profound challenges. The first and the reason for its formation was environmental challenges such as draughts, famine and environmental degradation hence was launched as Inter-governmental Authority on Drought and Development (IGADD) (IGAD 1996, Ameyo 2010). Surrounding the formation of IGADD was the epic famine of 1984/5 that devastated Ethiopia (Tareke 2009). It was presumed to have taken the life 1.2 million Ethiopians (Gill 2010). It spurred a world musical gala by Band Aid followed by We are the World that brought together world artists to raise money for the victims of famine. The dynamic induced the initiative for the region to mobilise and organise itself that culminated in the emergence of IGADD. IGADD was a product of environmentally induced problems of draught, famine, poverty, etc. The initiative to establish a regional organisation hailed from the UN, as represented in the UN General Assembly Resolution 38/216 on 20 December 1983 (Ameyo 2010). In January 1986, six heads of state and government of the region convened in Djibouti and announced the establishment of IGADD (Bereketeab 2012).

The second set of challenges entail peace, security, development and regional integration. Rampant intra-state and inter-state conflicts that devastate the region propelled the momentum for IGAD to redirect its objectives and mandates towards peace, security, development and regional integration that induced the reconfiguration of the regional organisation. This led to the birth of IGAD in 1996 (IGAD 1996). The third, the current challenge IGAD face is, the COVID-19 pandemic. If previous experiences could be of any indication the possibility IGAD would successfully deal with the pandemic is minimal. Neither is the possibility of a national state to deal with the pandemic brighter.

The interconnected nature as well as regional dimensions and dynamics of the conflicts is duly accentuated. This accentuation also underscores the need for regional, holistic approaches and mechanisms in resolving them. 'This is particularly important as the region represents a security complex, with interwoven conflict dynamics. The impact of COVID-19 will therefore take a regional dimension. Border closure and siloed responses will not contain it - it can only be overcome through a coordinated regional response' (PSC Report 2020: 2).

Preceding the COVID-19 pandemic, IGAD's success in meeting the complex challenges the region was facing was mixed. The IGAD region hosts the largest peacekeeping mission in Africa. In three out of eight of its member states are located peacekeeping missions: AMISOM (Somalia), UNMISS (South Sudan), UNAMIS (Sudan), UNISFA (SudanSouth Sudan) (El-Affendi 2001; Apuuli 2015; Adetula, Bereketeab and Obi 2020). The success of these missions however is very limited. Despite billions of dollars spent and years of efforts, the outcome is very modest. The lockdown has further affected the efficiency of these peacekeeping missions.

IGAD heads of state and government convened their first meeting in conjunction with the pandemic on 30 March that was followed by a meeting of IGAD ministers of finance on 9 April. Both meetings stressed the importance of mobilising region wide collective capacity to deal with the pandemic (IGAD 2020a, IGAD 2020b). At the same time, beyond the region they appealed for support from international community and international financial institutions to provided economic, medical equipment, medicines, face mask, body protection, testing kits, etc. The IGAD organs also highlighted the likelihood of reduction of remittances that have been a life line for many communities in the region due to the global pandemic. Finally, the meeting of the IGAD Ministers of Finance Meeting concluded by issuing, 
The IGAD regional taskforce on Pandemics which will further facilitate knowledge generation ad sharing among IGAD Member States, administrate the regional emergency fund on pandemics and support the expansion and role of digital economy to counteract the economic effects of restrictions in movement and travel. Further, the study will have to identify specific border-crossing areas between member countries that are designated as potentialpoints of transmission and essential to trade, as well as the cost of strengthening and where necessary establishing health facilities to counter COVID-19 and provide necessary detection and control capabilities like testing kits, personal protective equipment as well as quarantine \& isolation facilities (IGAD 2020b: 4).

The statement testifies to the fact that IGAD is aware of the immense challenges the pandemic poses and the limited capacity the region possesses. It also confirms IGAD's commitment to deal with the pandemic. At a policy level, IGAD's initiative looks promising. As usual, the bottleneck is implementation. It is well known that IGAD suffers from various shortcomings that affect its implementation capacity. These shortcomings include financial, professional, structural, institutional, internal cohesion and vision. For IGAD to meet its mandates and objectives, particularly successfully fight the pandemic need to go through third round of reform and reconfiguration (the first was in 1986 while the second was in 1996). The inter-state conflicts, particularly, the Ethiopia-Eritrea conflict considerably weakened IGAD (Apuuli 2015, Bereketeab 2012). Ethiopia, under the previous government, systematically used IGAD for its own national interest and for ten years refused to vacate the chair that alienated my members and severely damaged the regional organisation. Eritrea is reluctant to reactivate its membership that contribute to the feebleness of the organisation (Andemariam 2020).

\subsection{Test of Global Solidarity}

Arguably, we live in a globalised world and quite often we tell ourselves cosmopolitanism is the new order defining our humanity. Ideally, at least, in principle, globalisation and view of common humanity should also be translated into equitable sharing of our common global resources. Global solidarity, its philosophical and moral foundation, is a derivative of globalism. Globalism in turn rests on the notion of cosmopolitanism. Cosmopolitanism, according to Stanford Encyclopedia of Philosophy (2019), means citizen of the world. All human beings are citizens of a single community. As citizens of single community, are we then entitled for the same and equal treatment and services. Citizenship entails rights and obligations. How congruent our believes and practical actions are in conjunction with the lofty ideas of common humanity? Is it meant that a congruency should prevail? 'most people agree that cosmopolitan principles of justice are correct in the abstract, but this widespread agreement does not appear to motivate cosmopolitan action. We have been persuaded to 'believe' in cosmopolitanism, but we are not 'doing' cosmopolitanism' (Lenard et al 2010: 100). The current COVID-19 pandemic has truly tested our belief of common humanity. Indeed, it has demonstrated the cleavage between preaching and deeds.

Genuine global solidarity is tested during crisis. The maxim that 'we only know our real friends in time of difficulties' was proven in this terrible time of pandemic. The pandemic, at least initially, brought out unsettling human nature of egoism, greed, narrow nationalism and ethnocentrism. It seemed the lofty ideals of globalism, one village and common humanity was put aside. Powerful states engaged in hamstring, stealing, prohibiting lifesaving medical equipment such as facemasks, testing kits, etc. To many it came as a shock when the President of the EU Commission announced the banning of selling equipment outside the bloc, just a few weeks earlier the same President was in Addis Ababa and signed a wide range of trade and cooperation agreements with the AU. Critics would say applicability of global solidarity has 
only limited scope. The cynic, even would say, big powers preach it only when it suits their interest.

The COVID-19 pandemic have exposed the instrumentality of global solidarity. In spite of the well-known fact and common knowledge that Africa suffers of immense shortage of medical equipment, the EU resolved to deviate from the principle of sharing vital medical equipment. The EU president of the Commission was quoted in saying, 'We need to protect our health workers, who are in the first line of defense against the virus,' says Ursula von der Leyen' (Bayer, Deutsch, Vela and Tamma 2020). The decision on ban of selling of badly needed medical equipment was taken against the fact that it hurts most poor countries (Bown 2020). Nonetheless, the decision was taken. The manifestation of solidarity was tested within the EU region too. The behaviour of member states revealed that national states' interest remains much stronger than the continental organisation's.

What came as a surprise to many was that how within and between EU member states the spirit of selfishness was expressed. EU member states engaged in frenetic acts of prohibiting and hijacking of medical equipment. Incidents and anecdotes of these fre netic activities abound. 'But what is clear is that the oft-proclaimed solidarity among nations waging battle against the pandemic has been tested - if not shattered - by national and corporate selfinterest' (D'emilio 2020: 2).

A bealth official in France's hard-hit eastern region said U.S. officials swooped in at a Chinese airport to spirit aw ay a planeload of masks that France had ordered. "On the tarmac, the Americans arrived, take out cash and pay three or four times more for our orders, so we really have to fight," Dr. Jean Rottner, an emergency room doctor in Mulbouse, told RTL radio (D'emilio 2020: 2).

Germany accused the United States of employing 'Wild West Method' for diverting face mask from China destined to Germany. France was also reported of laying claim of Swedish medical supply destined to Spain and Italy. Switzerland introduced restrictions for companies to export protective medical devices without permission from the government. Italy also introduced its own restriction of exporting masks and disposables. Many of the EU member states seemed to engage in acts that undermine the very solidarity that is supposed to be the foundation of the Union (D'emilio 2020, Boffey 2020). The closure of national borders have affected people, particularly mixed and interdependent trans-border communities. In the case of the Scandinavian countries, for instance, closure of borders separating closely integrated border communities not only have affected the people there but also raised questions of the meaning and validity of the Nordic solidarity and integration.

Another worrying information disseminated in early July was that the USA has already bought all vaccinations that are on the pipeline. If affluent countries could monopolise medical products that should be shared solidarily by all, using their privileged status renders the notion of common humanity hollow. In addition, while people in developing nations are finding it extremely difficult to meet their daily need of a piece of bread, affluent gove rnments in the West are spending billions of dollars bailing out corporate companies.

\subsection{Opportunities for Regional Capacity Building}

The pandemic could also provide an opportunity, not only problems. As explained above the states in the region suffer from multiple deficiencies. Some of these deficiencies entail resources and capacities. With regard to natural resource endowment the region is highly endowed. Its youthful population is also an indispensable asset. What is needed is building regional capacity. Arguably, the pandemic as well as the other pathologies afflicting the region 
is beyond the capacity of individual states to deal with. To meet the challenges the region as well as the continental organisation (AU) need to mobilise and organise all its resources. Mobilisation, organisation and bringing together resources, capacities, human, intellectual, material, institutional and organisational endowments is an indispensable measure that enable the region to deal with the pandemic. The greater Horn need to think beyond the twilight of COVID-19 pandemic. The potential to convert problems to opportunities is now vividly hanging over the leaders of the region. Properly utilising the momentum and dynamics the pandemic had proffered and tune a new mind-set of the prioritisation and sensitisation of internal (national and regional) capacities, resources and agency would not only serve in combating the current pandemic, but also galvanise and energise the region in dealing with all its problems. The mobilisation and organisation of resources and capacities goes beyond technical and administrative measures. It requires a change of frame of mind that implores creative, innovative and systematic utilisation of those items, most importantly developing a culture that fosters independence, agency and ownership.

The proposed mobilisation and organisation strategies purportedly would refer to relation between three entities, notably national states, RECs (regional economic communities) and AU. An organisational structure that ties the three entities in an institutionalised and formalised manner is of a great imperative if the RECs as well as the AU are to deal with the complex problems they face. The AU recognises the three-tier structure states, RECs and AU - as component units of the continental organisation. Nevertheless, the recognition has not been translated into legal formal and institutionalised manner of exercising responsibility, accompanied by accountability and sanctions. Once, the three tier organisational structure is formalised and institutionalised, the units will be allotted mandates and responsibilities dispersed on the basis of principle of subsidiarity. The clear division of labour will then illustrate mandates and responsibilities of each level.

This coherent and stringent organisational structure would enable the continent to organise and mobilise own resources: human, material intellectual, institutional and ideational. The mobilisation of own resources would mean escaping dependence on external "benevolence", which is not always an act of genuine altruism. In addition, to the materialisation of the mantra 'African solutions for African problems', it would also confer legitimacy on the entities (national states, RECs, AU). The pandemic proffers an indispensable opportunity for the RECs and the AU to embark on genuine novelty of restructuring the continent along the three tiers, mobilise and organise own resources and capacities. This would have an emancipatory long-term effect in the continent.

\section{Conclusion}

\subsection{Overall Contribution}

This article examined the challenges of the COVID-19 pandemic in the IGAD region. It provided explication of two set of challenges, notably epidemiological and socio-economic. It also analysed the role IGAD played in addressing the pandemic. The article concludes that the pandemic proffers both challenges and opportunities. In terms of the challenges, it assessed the aggravating effects to the already precarious economic, social and health situation. Epidemiologically, it demonstrated how the vulnerability of the health system was jetted to a maximum scale. The preliminary study demonstrate that socio-economic consequences are more severe than epidemiological. The article also infers early strong measures such as lockdown, state of emergency and curfews helped mitigating the spread of the pandemic. The same measures also deprived people, particularly the downtrodden section of society, of basic 
livelihood. The article advanced the view that addressing the pandemic demands pulling together all the pools of the region that pertain to mobilisation and organisation of resources and capacities (material, intellectual, ideational and technological).

In terms of opportunity, the article assessed the pandemic, have opened a chance for the region to mobilise common capacity to deal with the pandemic, instead of depending on outside support. The chance should not be missed. IGAD, as regional organisation, is supposed to play leading role in mobilising, organising and implementing regional initiatives, although it displays serious weakness in discharging its responsibilities.

\subsection{Limitations and Further Contributions}

Proper mapping and analysis of the consequences of the COVID-19 pandemic requires further thorough study. Since the pandemic is still going on, we will not be able to assess the actual consequences. In terms of socio-economic consequences, we already know the consequences are serious. Yet, further study is required to determine definitely how deep and how long lasting are the consequences. At the same time, we have enough clues of the necessary innovative measures that are needed to ensure success in the fight against the pandemic and beyond, notably effective mobilisation and organisation of domestic resourc es. Further study could help us:

- How to mobilise and organise internal resources and capacity effectively

- How to avid dependency on donors and aid agencies

- Identify future challenges

- What necessary measure should be taken to mitigate consequences of pandemics

\section{References}

Adetula, Victor, Bereketeab, Redie and Obi, Cyril. 2020. Regional Economic Communities and Peacebuilding in Africa: Lessons from ECOWAS and IGAD. London: Routledge

Ameyo, Dan K. 2010. 'Study on the Comprehensive Review of the Agreement Establishing the Intergovernmental Authority on Development, unpublished paper

Andemariam, Senai W. 'The IGAD-Eritrea Impasse: Future Prospects in Light of Recent Developments', in Victor Adetula, Redie Bereketeab and Cyril Obi (eds.), Regional Economic Communities and Peacebuilding in Africa: Lessons from ECOWAS and IGAD. London: Routledge

Appuli, Kasaija Phillip. 2015. 'IGAD's Mediation in the Current South Sudan Conflict: Prospects and Challenges', African Security, vol. 8, no. 2, pp. 120-145

Assal, Munzoul. 2020. 'Covid-19 and the Challenges of Social Distancing in Khartoum', Chr. Michelsen Institute. https://www.cmi.no/countries/sudan. Accessed on 20-07-2020

Bayer, Lili; Deutsch, Jillian; Vela, Jakob Hank; Tamma, Paola. 2020. EU to Limit Exports of Medical Equipment outside Bloc. https://www.politico.eu/article/coronavirus-eulimit-exports-medical-equipment/. Accessed on 21-06-2020

Bereketeab, Redie. 2020a. 'State Legitimacy and Government Performance in the Horn of Africa' African Studies, vol. 79, no. 1. pp. 51-69

Bereketeab, Redie. 2020. Covid-19 and Eritrea's Response. Kujenga Amani, SSRC-APN

Bereketeab, Redie (ed.). 2013. The Horn of Africa: Intra-State and Inter-State Conflicts and Security. London: Pluto Press

Bereketeab, Redie. 2012. 'Inter-governmental Authority on Development (IGAD): A Critical Analysis', in Kidane Mengisteab and Redie Bereketeab (eds.), Regional Integration, Identity and Citizenship in the Greater Horn of Africa. Woodbridge and Rochester: James Currey 
Bereketeab, Redie. 2009. State-building in Post-Liberation in Eritrea: Challenges, Achievements and Potentials. London: Adonis and Abbey Publishers

Boffey, Daniel. 2020. 'Italy Criticises EU for being Slow to Help over Coronavirus Epidemic', The Guardian, $11 \quad$ March 2020. https://www.theguardian.com/world/2020/mar/11/italy-criticises-eu-being-slowhelp. Accessed on 05-07-2020

Bown, Chad P. 2020. EU limits on medical gear exports put poor countries and Europeans at risk. https://www.piie.com/blogs/trade-and-investment-policy-watch/eu-limitsmedical-gear-exports-put-poor-countries-and. Accessed on 21-06.2020

Cilliers, Jakkie et al. 2020. 'The Poor Lose Again: Impact of COVID-19 on Africa', Institute for Security Studies. https://issafrica.org/iss-today/the-poor-lose-again-impact-ofcovid-19-on-africa. Accessed on 03-07-2020

D’emilio, Frances. 2020. 'Scramble for Virus Supplies Strains Global Solidarity', AP News, April 3, 2020. https://apnews. Com/b37eadbf9885767d01270117820f4b37. Accessed pm 04-07-2020

El-Affendi, Abdelwahab. 2001. 'The Impasse in the IGAD Peace Process for Sudan: The Limits of Regional Peacemaking?’, African Affairs, Issue 100, pp. 581-599

Elhakim, Mohamed, Tourab, Saleh Banoit and Zouiten, Ahmed. 2020. 'Covid-19 Pandemic in Djibouti: Epidemiology and the Response Strategy Followed to Contain the Virus During the First Two Months, 17 March to 16 May 2020', PLOS ONE. https://doi.org/10.1371/journal.pone.0243698.

Geyehu, Workineh. 2020. 'Can the Horn Deal with the Impact of COVID-19? A Keynote Speech, Webner Seminar Presentation, Convened by ISS, On June 10, 2020. https://issafrica.org/events/can-the-horn-deal-with-the-impact-of-covid-19

Gill, Peter. 2010. Famine and Foreigners: Ethiopia Since Live Aid. New York: Oxford University Press

ICG. 2020. Defining Ethiopia's Latest Perilous Crisis, 3 July 2020. https//www.crisisgroup.org/africa/horn-africa/ethiopia. Accessed on 01-10-2020

IGAD, 2020a. IGAD Heads of State and Government Declaration on the Coronavirus (Covid-19) Pandemic. Video-Conference, Monday, 30th March, 2020

IGAD. 2020b. Call for Action: IGAD Ministers of Finance Meeting on Response to the Covid-19 Pandemic. Online meeting on 9th April 2020

IGAD. 1996. Agreement Establishing the Inter-Government Authority on Development. Assembly of Heads of State and Government. Nairobi: IGAD/SUM-96/AGREDOC

Human Rights Watch. 2020a. 'Kenya : Police Brutality During Curfew', Human Rights Watch, April 22, 2020. https://www.hrw.org/news/2020/04/22/kenya-police-brutalityduring-curfew. Accessed on 20-07-2020

Human Rights Watch. 2020b. 'Uganda: Respect Rights in Covid-19 Response', Human Rights Watch, https://www.hrw.org/news/2020/04/02/uganda-respect-rights-covid-19response\#. Accessed on 20-07-2020

Lenard, Patti Tamara et al. 2010. 'Global Solidarity', Contemporary Political Theory, vol. 9, no. 1 , pp. $99-130$

Madeira, Francesco Caetano Jose. 2020. The Effect of COVID-19 on AMISON Operations in Somalia. ACCORD, October 14, 2020. Accord.za/analyses/the-effects-covid-19on-amisom-operation-in-somalia. Accessed on 10-10-2020

Mengisteab, Kidane. 2014. The Horn of Africa. Cambridge and Malden: Polity Press

PSC Report. 2020. Towards a Regional Response to COVID-19 in the Horn. ISS/PSC Report, 22 April 2020

Schmidt, Elizabeth. 2018. Foreign Intervention in Africa After the Cold War: Sovereignty, Responsibility, and the War on Terror. Athens, Ohio: Ohio University Press 
Serels, Steven. 2020. Epidemics in the African Red Sea Region: A History of Uneven Disease Exposure. Rift Valley Institute. www.riftvalley.net

Stanford Encyclopedia of Philosophy. 2019. Cosmopolitanism. file://C:/Users/redibere/Work Folders/Documents/Cosmopolitanism/(Stanford Encyclopedia of Philosophy).htm Accessed on 05-07-2020

Tareke, Gebru. 2009. The Ethiopian Revolution: War in the Horn of Africa. New Haven \& London: Yale University Press

Wakiaga, James. 2020. 'UNDP COVID-19: Leveraging on Social Capital to 'Flatten the Curve' in Eritrea', James Wakiaga, Resident Representative, UNDP Eritrea. https://hezbawi.org/worldpress/?p=2552. Accessed on 15-10-2020

Weber, Annette. 2020. 'Covid-19 in the Horn of Africa: Gaining Trust in a Crisis', SWP Comment, German Institute for International and Security Affairs, No. 20 May 2020

Woodward, Peter. 2013. Crisis in the Horn of Africa: Politics, Piracy and the Threat of Terror. London and New York: I. B. Tauris

World Bank. 2020. Community Responses to COVID-19: From the Horn of Africa to the Solomon

Islands. https://www.worldbank.org/en/news/feature/2020/05/19/community-responsesto-cov... Accessed 30-06-2020

Yordanov, Radoslav A. 2016. The Soviet Union and the Horn of Africa During the Cold War: Between Ideology and Pragmatism. Lanham, Boulder, New York, London: Lexington Books 